\title{
Activity of Noni Fruit (Morinda citrifolia L.) Ethanolic Extract on Class mu Glutation S-Transferase of Lung Rat
}

\author{
Purwanto Purwanto $^{1 *}$, Sudibyo Martono ${ }^{2}$ \\ ${ }^{1}$ Department of Pharmaceutical Biology, Faculty of Pharmacy, Universitas Gadjah Mada, Yogyakarta, Indonesia \\ ${ }^{2}$ Department of Pharmaceutical Chemistry, Faculty of Pharmacy, Universitas Gadjah Mada, Yogyakarta, Indonesia
}

\begin{abstract}
One of the main modalities of cancer treatment is chemotherapy, which uses chemicals that are generally electrophilic. These xenobiotic compounds sometimes does not produce effective response due to activity of glutathione S-transferase (GST) which inactivate the xenobiotics. Several natural phenolic compounds were reported to inhibit GST activity in vitro. Noni fruit (Morinda citrifolia L.) which contains flavonoids and other phenolic compounds such as scopoletin and morindon is proposed to interfere GST activity. This study aimed to analyze the effect of ethanolic extract of Noni fruit in vivo on GST activity in lung rat using 1,2-dichloro-4-nitrobenzene (DCNB). This substrate is a specific for class mu GST. First, rats were administered with ethanolic extract of Noni and dimethylbenz(a) anthracene (DMBA) for two weeks. The cytosolic fraction of lung was isolated then the GST activity was determined by simple kinetic program which was automatically calculated using spectrophotometer. The results showed that ethanolic extract of Noni in 1 and 5\% $(\mathrm{w} / \mathrm{v})$ of concentration induced class mu GST activity, whereas $10 \%(\mathrm{w} / \mathrm{v})$ of concentration inhibited class mu GST activity. After a treatment with DMBA, all tested concentrations of ethanolic extract of Noni inhibited class mu GST activity of lung rat significantly. These results indicated that Noni fruit extract can be further developed as a supportive agent of a chemotherapy drug.
\end{abstract}

Keywords: DMBA, GST, Morinda citrifolia L., spectrophotometer.

\section{INTRODUCTION}

Cancer is one of the leading causes of death in industrialized and developing countries with an estimation of 18.1 million of new cases and 9.6 million of cancer deaths (Bray, et al., 2018). Several methods of cancer therapy have been carried out intensively, such as surgery, chemotherapy, radiation, and hormonal therapy. Unfortunately, several chemotherapeutic agents are failure because of increasing of glutathione
$S$-transferase (GST) activity. This enzyme accelerates the elimination process of electrophilic xenobiotic (Allocati, et al., 2018). For this reason, efforts are needed to reduce the GST activity in order to increase the efficacy of chemotherapeutic agents with electrophilic xenobiotics such

Submitted: January 3, 2020

Revised: February 28, 2020

Accepted: February 28, 2020

*Corresponding author: purwanto_fa@ugm.ac.id 
as

cisplatin, 5-fluorouracil, and adriamycin.

Glutathione $S$-transferase is a superfamily enzyme which is naturally found in both eukaryotes and prokaryotes. According their cellular localiation, GSTs in eukariotes are divided into three families, that are cytosolic, mitochondrial, and microsomal GST (Sheehan, et al., 2001; Oakley, 2011). This enzyme is found in several tissues such as liver, kidney, lung, and small intestine (Van Haaften, et al., 2003). Based on the structure and function, GST is grouped into 12 classes including alpha, zeta, mu, phi, sigma, omega and theta (Antonella, et al., 2003; Oakley, 2011) depending on their amino acid sequence (Guneidy, et al., 2017). To analyze GST activity, a substrate that is specific to certain GST isoenzymes can be used. The 7-chloro-4-dinitrobenzo-2-oxa-1,3-diazol (CDNB) is a common substrate used for all classes of GST (Sheehan, et al., 2001).

GST has several important biological roles, including involve in the synthesis of leukotriens and prostaglandins, cell protection against toxic molecules and oxidative stress (Hayes, et al., 2005) and catalyzes conjugation of electrophilic xenobiotics (including many carcinogens) with glutathione $(\mathrm{GSH})$ to make a hydrophilic molecules which easier to be eliminated in a metabolism process. This faster elimination of electrophilic xenobiotics eventually causes resistance to cytostatic drug (Allocati, et al., 2018).

Natural phenolic compounds such as polyphenols, flavonoids, and curcumin have been known as inhibitor compounds of GST activity in vitro (Sudibyo, 2000; Hamed, et al., 2014; Arinc and Yilmaz, 2014; Guneidy, et al., 2017). Other research reported that pentagamavunon-0 (a curcumin analoque) inhibited class $m u$ GST activity but not of class phi of rat kidney (Sudibyo and Supardjan, 2002).

Mengkudu (Morinda citrifolia L.) which is known as Noni has been used by Polynesians as a traditional drug for more than 2000 years (Wang, et al., 2002). This herb is reported to have extensive therapeutic effects as antibacterial, antiviral, antitumor, analgesic, hypotensive agent, antiinflammatory and immune system enhancement (Wang, et al., 2002; West, et al., 2018). Several active compounds have been identified from Noni fruit including scopoletin (a phenolic coumarin), anthraquinone, flavonoids, carotenoids, rubiadine, terpenoids, noniosides, morindon, and beta carotene (Almeida, et al., 2019). Ethanolic extract of Noni at 26.6 and $133.1 \mathrm{mg} / \mathrm{kg}$ body weight administered orally to experimental rat was reported able to increase activity of class $m u$ GST in liver (Atiah, 2006) and kidney organ (Rosaningtyas, 2006). This study aimed to analyze the effect of ethanolic extract of Noni fruit in vivo on GST activity in lung rat induced by DMBA using 1,2-dichloro-4nitrobenzene (DCNB) substrate which is a specific substrate for class $m u$ GST.

\section{MATERIALS AND METHODS}

\section{Materials}

Matured Noni fruit was taken at the Faculty of Pharmacy, Universitas Gadjah Mada, Yogyakarta, Indonesia. The Noni fruit was yellowish green in color. Male rats (Wistar strain), 2 months of age, 175-210 g of weight were from Sanggar Kegiatan Belajar, Bantul, Yogyakarta, Indonesia. Bovine serum albumin (BSA), 7,12-dimethyl benz( $\alpha$ )anthracene (DMBA), and 1,2-dichloro-4-nitrobenzene (DCNB) were purchased from Sigma (St. Louis, Missouri, USA). Glutathione (GSH), ethanol, sodium carbonate, sodium nitrite, aluminium chloride, sodium hydroxide, potassium dihydrogen phosphate, dipotassium hydrogen phosphate, copper sulphate pentahydrate, Folin-Ciocalteu reagent and potassium sodium tartrate were purchased from Merck (Darmstadt, Germany). Corn oil was purchased from PT. Nutrifood Indonesia, Bogor, Indonesia.

\section{Methods}

Preparation of Noni extract

A number of $5 \mathrm{~kg}$ of fresh Noni fruit were 
blended and macerated with $70 \%$ ethanol in a closed vessel for 3 days while stirring occasionally. The obtained filtrate was evaporated using vacuum rotary evaporator (Heidolph VV 2000) at $60^{\circ} \mathrm{C}$, then dried by freeze drying (Free Zone ${ }^{\circledR}$ ). A number 45 $\mathrm{g}$ of dried extract were collected. The determination of phenolic compounds in dried extract of Noni was performed with Folin-Ciocalteu reagent.

\section{Maximum Wavelenght and Operating Time Measurement for Protein Determination}

The Lowry method used in protein determination is a simple and specific method with high reproducibility and still shows good sensitivity at low concentration up to $5 \mu \mathrm{g}$ protein. From this measurement, obtained operating time was 45-55 $\min$ and $\lambda \max 749 \mathrm{~nm}$.

\section{Treatment of Experimental Rat}

A number of 50 male rats were randomly divided into 10 groups which consist of 5 rats each group. Each group was placed in one cage. Feed and drinking water were replaced every day, while the husks were replaced every two days. The cages were placed in room with $25^{\circ} \mathrm{C}$ of temperature and lighting (approximately 15 Watt lamps) on for $8 \mathrm{~h}$ and off for $16 \mathrm{~h}$. For adaptation purpose, rats were kept in the cages for one week. For the treatment of each group, it can be seen at Figure 1. Since the dried extract of Noni was completely dissolved in water, we did not use a suspending agent such carboxy methyl cellulose for this purpose.

\section{Preparation of Pulmonary Cytosolic Fraction}

After the treatments were completed, rats were fasted for $24 \mathrm{~h}$ before being sacrificed by cervical dislocation and their lungs were taken for the preparation of the cytosolic fraction containing GST by multilevel centrifugation method (Hitachi SCP $85 \mathrm{H}$ ) according to Lundgren, et al. (1987) with a slight modification, that are time and variation of ultracentrifugation speed. Determination of protein content was carried out by spectrophotometry using Lowry method and BSA comparison standard at maximum wave length.

The organ was taken after the rats had been fasted for $24 \mathrm{~h}$ (only given by tap water) to minimize the nutritional content of food in the blood which might affect the GST activity. Lung was homogenized by a cold blender $\left(4^{\circ} \mathrm{C}\right)$ at 440 $\mathrm{rpm}$ in phosphate buffer ( $\mathrm{pH} 7.5)$ to avoid extreme changes which disrupt the its biological activity

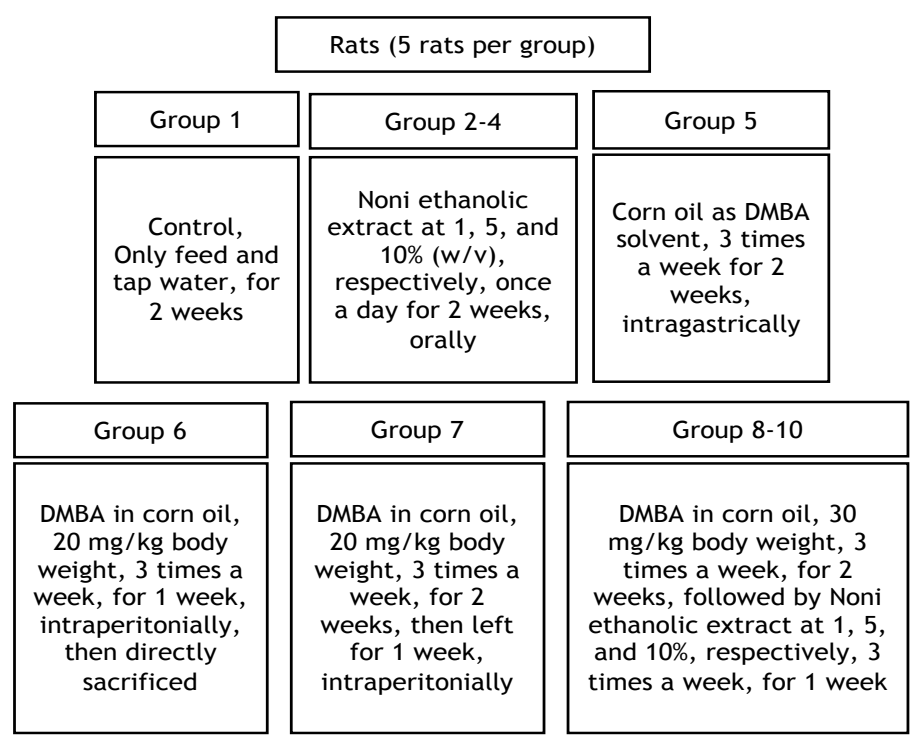

Figure 1. The treatment of each rat group. 
(Murray, et al., 1995). Specimen were centrifuged at $10.000 \mathrm{x} \mathrm{g}$ for $30 \mathrm{~min}$ at $4^{\circ} \mathrm{C}$ to precipitate the collapse of the cells, cell nuclei, and mitochondria. The supernatant was collected and recentrifuged at $105.000 \mathrm{x} \mathrm{g}$ for $90 \mathrm{~min}$ to precipitate microsomes. The supernatant from this step was cytosolic fraction containing unrefined GST.

\section{Determination of GST Activity}

The determination of GST activity was performed with DCNB as the substrate (Habig, et al., 1974). Incubation mixture consisted of 0.1 M phosphate buffer $\mathrm{pH} 7.5$; cytosol fraction; 50 $\mathrm{mM} \mathrm{GSH}$ and $50 \mathrm{mM}$ DCNB. As the blank, $0.1 \mathrm{M}$ phosphate buffer $\mathrm{pH} 7.5$ was used. The GS-CNB conjugate product was measured at $\lambda 345 \mathrm{~nm}$ with simple kinetic methods using a spectrophotometer (Genesys-5 Milton Roy). The measurement results are a rate of reaction ( $\Delta$ absorption per minute). Protein concentration in the cytosol fraction was determined by Lowry methods (Lowry, et al., 1951) using bovine serum albumine (BSA) to make a protein standard curve.

\section{Calculation of Percent (\%) Inhibition or Induction}

From the absorbtion measurement of GSCNB conjugate product, the value of $\Delta$ absorption per minute (rate) was obtained.

$\mathrm{V}=\mathrm{GST}$ activity (nmol.min- $1 / \mathrm{mg}$ protein)

$\mathrm{V}=$ Rate $/ \Delta \varepsilon \mathrm{GS}-\mathrm{CNB}$, cuvette thickness/protein concentration in the mixture

$\Delta \varepsilon \mathrm{GS}-\mathrm{CNB}=8.5 \mathrm{mM}^{-1} \mathrm{~cm}^{-1}$

\section{Percent inhibition or induction $=[(\mathrm{V}$ control $-\mathrm{V}$} treatment) / $\mathrm{V}$ control] $\times 100 \%$

\section{Data Analysis}

Since the obtained data of GST activity calculation were parametric, the Anova test was carried out by SPSS for Windows program to see whether there were differences between control and treatment of administration of Noni fruit extract and DMBA in GST activity.

\section{RESULTS}

\section{Ethanolic Extract of Noni Contained Phenolic Compounds}

Determination of phenolic compounds in dried extract of Noni was positive because it formed a blue color with the Folin-Ciocalteu reagent. This method used sodium carbonate because reaction of phenolic subtances with the Folin-Ciocalteu reagent occurs in an alkaline atmosphere (Prior, et al., 2005).

Tabel 1. GST activity of each treatment measured by spectrophotometry.

\begin{tabular}{ccc}
\hline Group of Rat & $\begin{array}{c}\text { Protein Content } \pm \text { SD } \\
(\mathrm{mg} / \mathrm{mL})\end{array}$ & $\begin{array}{c}\text { GST Activity } \pm \text { SD } \\
\left(\mathrm{nmol}^{-1} \mathrm{~min}^{-1} / \mathrm{mg} \text { Protein }\right)\end{array}$ \\
\hline I & $0.0895 \pm 5.29 \times 10^{-4}$ & $345.08 \pm 24.65$ \\
II & $0.0515 \pm 1.72 \times 10^{-3}$ & $402.58 \pm 23.46$ \\
III & $0.0664 \pm 9.02 \times 10^{-4}$ & $413.85 \pm 18.28$ \\
V & $0.0711 \pm 3.06 \times 10^{-4}$ & $310.52 \pm 21.95$ \\
VI & $0.0866 \pm 1.01 \times 10^{-3}$ & $331.11 \pm 31.19$ \\
VII & $0.0511 \pm 5.51 \times 10^{-4}$ & $319.48 \pm 38.62$ \\
VIII & $0.0929 \pm 2.78 \times 10^{-3}$ & $561.83 \pm 67.20$ \\
IX & $0.1008 \pm 3.93 \times 10^{-3}$ & $301.99 \pm 18.30$ \\
X & $0.1101 \pm 2.84 \times 10^{-3}$ & $198.54 \pm 15.60$ \\
\hline
\end{tabular}

Note:

Group 1, rats without treatment and were only given by food and drink for 14 days. Groups 2, 3, and 4, rats were given by ethanolic extract of Noni orally with level of 1,5 , and $10 \%$, respectively, once a day for 14 days.

Group 5, rats were treated by corn oil as DMBA solvent control, intragastrically, 3 times a week for 2 weeks. Group 6, rats were treated by DMBA in corn oil, intraperitonially at a dose of $20 \mathrm{mg} / \mathrm{kg}$ body weight, 3 times a week for 1 week.

Group 7, rats were treated by DMBA in corn oil, intraperitonially at a dose of $20 \mathrm{mg} / \mathrm{kg}$ body weight, 3 times a week for 2 weeks and left for 1 week. Group 8, 9, and 10, rats were treated by DMBA in corn oil, intraperitonially at a dose of $20 \mathrm{mg} / \mathrm{kg}$ body weight, 3 times a week for 2 weeks followed by ethanolic extract of Noni fruit orally at level of 1, 5, and $10 \%$, respectively, in distilled water, once a day for 7 days. 


\section{Measurement of GST Activity}

The measurement of conjugate product was carried out at $\lambda 345 \mathrm{~nm}$, which is the maximum wavelength of GS-CNB complex. The measurement was also linear within 3 minutes with changes in absorption less than 0.05 per minute. Therefore, measurements of the conjugate product were performed from minute 0 to 3 . The results of determination of GST activity showed that treatment with ethanolic extract of Noni at 1 and $5 \%$ of dose (group II and III) and DMBA for 2 weeks (group VII) increased the GST activity. Interestingly, the GST activity decreased after DMBA treatment which followed by extract etanolic of Noni (group VIII-X), as shown in Table 1.

\section{Ethanolic Extract of Noni Inhibited GST Ac- tivity After Treatment with DMBA}

A compound has the ability to inhibit GST activity if its GST activity value is smaller than the control, whereas it has an inducing activity when the GST activity value due to the treatment is greater than control. The results of the calculation of the percentage values are listed in Table 2 and 3.

Tabel 2. The induction percentage of GST activity compared to control.

\begin{tabular}{ccc}
\hline Group of Rat & $\begin{array}{c}\text { GST Activity } \pm \text { SD } \\
\text { (nmol.min }-1 / \mathrm{mg}^{2} \text { Protein) }\end{array}$ & $\begin{array}{c}\text { Induction Percentage } \\
(\%)\end{array}$ \\
\hline Without treatment & $345.08 \pm 24.65$ & - \\
Corn oil 2 weeks & $331.11 \pm 31.19$ & - \\
Extract $1 \%$ & $402.58 \pm 23.46$ & $16.66^{\mathrm{a}) *}$ \\
Extract $5 \%$ & $413.85 \pm 18.28$ & $19.93^{\mathrm{a}) *}$ \\
DMBA 2 weeks & $561.83 \pm 67.20$ & 69.79 b)* \\
\hline
\end{tabular}

a) = GST activity compared to control (without treatment)

b) = GST activity compared to corn oil 2 weeks

* = statistically significant $(p=0.05)$

Induction percentage was counted by the mean data

\section{DISCUSSION}

This study aimed to analyze the effect of ethanolic extract of Noni fruit on GST activity in lung rat. Ethanol was chosen in the extraction process of the active compounds because it is a universal solvent which can dilute many kind of chemi-
Tabel 3. The inhibition percentage of GST activity compared to control.

\begin{tabular}{ccc}
\hline Group of Rat & $\begin{array}{c}\text { GST Activity } \pm \text { SD } \\
\text { (nmol.min } \text { m }^{-1 / m g} \\
\text { protein) }\end{array}$ & $\begin{array}{c}\text { Inhibition } \\
\text { Percentage (\%) }\end{array}$ \\
\hline Without treatment & $345.08 \pm 24.65$ & - \\
DMBA 2 weeks & $561.83 \pm 67.20$ & - \\
$\quad \begin{array}{l}\text { Extract 10\% } \\
\text { DMBA 2 weeks + } \\
\quad \text { extract 1\% }\end{array}$ & $310.52 \pm 21.95$ & 10.01 a) \\
$\begin{array}{c}\text { DMBA 2 weeks + } \\
\text { extract 5\% }\end{array}$ & $198.54 \pm 15.60$ & $46.25^{\text {b)* }}$ \\
$\begin{array}{c}\text { DMBA 2 weeks + } \\
\text { extract 10\% }\end{array}$ & $272.87 \pm 15.157$ & $64.66^{\text {b)* }}$ \\
\hline
\end{tabular}

a)= GST activity compared to control (without treatment)

b) = GST activity compared to DMBA 2 weeks

* = statistically significant $(p=0.05)$

Inhibition percentage was counted by the mean data

cal compounds. Alcoholic solvent such as ethanol $70-80 \%$ is the best choise for extracting flavonoids (Robinson, 1995), as contained in Noni fruit. Extraction vessels were placed in the dark place and wrapped in a black chamber in order to reduce the influence of sunlight because the presence of sunlight can induce the damage of chemical contents especially flavonoids.

Because there was no purification of obtained GST, enzyme activity was measured in micromole product yielded per minute per milligram protein in the final incubation medium. In other word, determination of GST activity was carried out to find out how much enzyme that catalyzed the conjugation reaction of GSH and DCNB measured by spectrophotometry (Habig, et al., 1974). Phosphate buffer was used as reaction medium because it did not inhibit GST activity (Clark, et al., 1991). The $\mathrm{pH}$ value used was 7.5 because optimum GSH conjugation reaction with DCNB was in that $\mathrm{pH}$ value (Habig, et al., 1974). Other research also showed that the conjugation reaction of GSH and DCNB was optimum at $\mathrm{pH} 7.5$ to 9.0 (Booth, et al., 1961). Sudibyo (1997) also reported that $0.1 \mathrm{M}$ phosphate buffer at $\mathrm{pH} 7.5$ was the optimum reaction condition of GST from rat liver to its substrate.

It is known that DMBA that is included in polycyclic aromatic hydrocarbons (PAHs) will form a dihydrodiol epoxide in the presence of cyto- 
chrome P-450 and microsomal hydrolase epoxide. This metabolite will bind with nitrogen atom number 7 (N7) or carbon atom number $8(\mathrm{C} 8)$ of purine bases and forming a unstable products and trigger the formation of apurinic sites (AP) as a result of a spontaneous depurination process (Melendez-colon, et al., 1999; McCarty, et al., 2009). Epoxide compound which is easy to be an electrophylic form will induce the expression of GST, a phase II metabolism enzyme. The electrophylic compound will be conjugated with glutathione to be a hydrophilic metabolite and easy to eliminate (McCarty, et al., 2009). GST induction might be mediated by antioxidant response elements and its transcription factor Nrf2, which is involved in the induction of many phase II enzymes (Thimmulappa, et al., 2002).

As shown in Table 2, treatment with DMBA for 2 weeks increased GST activity $69.79 \%$. GST plays a regulatory role in cellular signaling in the process of protein interactions with critical kinases involved in controlling stress response, apoptosis and proliferation (Mcllwain, et al., 2006). That is why in cancer case, GST activity will increase and cancer treatment with some electrophilic drug will not be effective.

From Table 2, it can be seen that treatment of Noni extract at concentration 1 and $5 \%$ increased GST activity. Some phenolic compounds were reported to be involved in the induction cellular defence system including detoxifying and antioxidant enzyme systems (Huang, et al., 2010). Flavonoids also induce enzyme expression of phase II biotransformation such as GST and quinon reductase (Ren, et al., 2003). This induction effect of GST activity might be because of iridoid, a natural product found in Noni fruit. Iridoid was reported to induce GST activity at $100 \mu \mathrm{M}$ (Mukanganyama, et al., 2011). It is interesting because iridoid was also reported to inhibite GST activity at low concentration but induce it at high concentration. Those opposite results indicate that there could be other molecular interactions occuring the substrates and the enzyme. Contrary to iridoid and some flavonoid which induce GST activity, other research reported that some kind of flavonoids such as quercetin and hesperidin inhibited GST activity competitive mechanism; naringenin and rutin by mixed-type mechanism (Arinc and Yilmaz, 2014; Karakurt, et al., 2015); while ellagic acic inhibited GST activity by noncompetitive mechanism (Karakurt, et $a l ., 2015)$. It indicate that different chemical structrure including phenolic content in Noni fruit, such as such as scopoletine, proxironine, and flavonoids including morindon and rubiadin (Bangun and Sarwono, 2002) could have difference binding site at GST enzyme and produce difference effect as Arinc and Yilmaz (2004) and Karakurt, et al. (2015) mentioned.

In other results, as shown in Table 3, the administration of Noni fruit extract was able to inhibit GST activity after administration of DMBA significantly ( $p=0.05$ ). Extract with 1,5 , and $10 \%$ content inhibited GST activity of 46.25; 64.66 and $59.44 \%$, respectively. This is beneficial when administration of Noni is combined with chemotherapy agent such as adriamycin, cisplatin, 5-fluorouracil, and vincristine because the therapeutic effect of those agents will be optimum (Ali, et al., 2016). Wang, et al. (2002) reported that ethanolic extract of Morinda citrifolia L. were able to indirectly suppress the tumor growth by increasing the immune response by inhibiting the production of tumor necrosis factor-alpha (TNF- $\alpha$ ), which is a promoter of endogenous tumors and interleukin-1, interleukin-12, and nitrate oxide (Brown, 2012).

\section{LIMITATION OF STUDY}

This study still needed many improvements in order to get adequate result and conclusion, including purification of the extract and determining the extract effect of Noni to several classes of GST.

\section{CONCLUSION}

Ethanolic extract of Morinda citrifolia L. at level 1 and 5\% induce GST activity. It means in this concentration, with more intensive research, the 
extract can be used as chemoprevention agent. In other hand, after treatment with DMBA, the extract inhibit GST activity which means it can be used as a promising supportive cancer therapy because the electrophilic drug such as busulfan and cisplatin are not eliminated too early.

\section{ACKNOWLEDGEMENT}

We gave a thank you for the Ministry of Research, Technology and Higher Education for providing funding for the research.

\section{REFERENCES}

Antonella, D.L., Bartolo, F., Erminia, C., Paolo, S. and Carmine, D.I., 2003, A novel amphibian Piclass glutathione transferase isoenzyme from Xenopus laevis: importance of phenylalanine III in the H-site, Biochem. J., 373, 539-545.

Ali, M., Kenganora, M. and Manjula, S.N., 2016, Health benefits of Morinda citrifolia (noni): a review, Pharmacogn. J., 8(4), 321-334.

Allocati, N., Masuli, M., Di llio, C. and Federici, L., 2018, Glutathione transferases: substrates, inhibitors and pro-drugs in cancer and neurodegenerative diseases, Oncogenesis, 7(8).

Almeida, E.S., de Oliveira, D. and Hotza, D., 2019, Properties and applications of Morinda citrifolia (noni): a review, Compr. Rev. Food Sci. Food Saf., 18, 883-909.

Arinc, E. and Yilmaz, D., 2014, Mechanism of inhibition of CYP1A1 and glutathione S-transferase activities in fish liver by quercetin, resveratrol, naringenin, hesperidin, and rutin, Nutrition and Cancer, 0(0), 1-8.

Atiah, N., 2006, Pengaruh ekstrak etanolik buah mengkudu (Morinda citrifolia L.) secara in vivo terhadap aktivitas glutation S-transferase hati tikus galur wistar, Thesis, Universitas Gadjah Mada, Yogyakarta.

Bangun, A.P. and Sarwono, B., 2002, Sehat dengan ramuan tradisional: Khasiat dan manfaat mengkudu, Agromedia Pustaka, Jakarta.
Booth, J., Boyland, E. and Sims, P., 1961, An enzyme from rat liver catalysing conjugations with glutathione, Biochem. J., 79, 516-523.

Bray, F., Ferlay, J., Soerjomataram, I., Siegel, R.L., Torre, L.A. and Jemal, A., 2018, Cancer statistic 2018: GLOBOCAN estimates of incidence and mortality worldwide for 36 cancers in 185 countries, CA Cancer, 68(6), 394-424.

Brown, A.C., 2012, Anticancer activity of Morinda citrifolia (noni) fruit: a review, Phytotherapy Research, 26, 1427-1440.

Clark, J.M., Hamilton, J.F., and Marshall, S.N., 1991, Inhibition by inorganic anions of glutathione S-transferase from insect and mammalian sources, Biochem. J., 278, 193-198.

Guneidy, R.A., Meguid, N.A., Abdel-Ghany, S.S., Saleh, N.S.M., Zaki, E.R. and Hamed, R.R., 2017, Inter-individual variation of normal and Down syndrome glutathione transferase in response to different phenolic compounds, Res. J. Pharm.Biol. Chem. Sci., 8(4), 184-201.

Habig, W.H., Pabst, M.J. and Jakoby, W.B., 1974, Glutathione S-transferases, the first enzymatic step in mercapturic acid formation, J. Biol. Chem., 249(22), 7130-7139.

Hamed, R.R., Ali, O.S., Guneidy, R.A. and Zaki, E.R, 2014, Inhibition of glutathione S-transferases by some Malvaceae flowers, Int. J. Curr. Adv. Res., 2(12), 174-187.

Hayes, J.D., Flanagan, J.U. and Jowsey, I.R., 2005, Glutathione transferases, Annu. Rev. Pharmacol. Toxicol., 45, 51-88.

Huang, W., Cai, Y. and Zhang, Y., 2010, Natural phenolic compounds from medicinal herbs and dietary plants: potential use for cancer prevention, Nutrition and Cancer, 62(1), 1-20.

Karakurt, S., Sever, M., Celebioglu, H.U. and Adali, O., 2015, Alteration of enzyme activities and kinetic properties of GST and NQO1 with naturally occuring phenolic compounds, Turkish J. Biochem., 40(3), 251-257.

Lowry, O.H., Rosebrough, N.J., Farr, A.L. and Randall, R.J., 1951, Protein measurement with the folin phenol reagen, Biochem. J., 193, 265-275. 
Lundgren, B., Meijer, J. and De Pierre, J.W., 1987, Characterization of the induction of cytosolic and microsomal epoxide hydrolases by 2-ethylhexanoic acid in mouse liver, Drug Metab. Dispos., 15, 14-121.

McCarty, K.M., Santella, R.M., Steck, S.E., Cleveland, R.J., Ahn, J., Ambrosone, C.B., North, K., Sagiv, S.K., Eng, S.M., Teitelbaum, S.L., Neugut, A.I. and Gammon, M.D., 2009, PAH-DNA adducts, cigarette smoking, GST polymorphisms, and breast cancer risk, Environ. Health Perspect., 117(4), 552-558.

Mcllwain, C.C., Townsend, D.M. and Tew, K.D., 2006, Glutathione S-transferase polymorphisms: cancer incindence and therapy, Oncogene, 25(11), 1639-1648.

Melendez-Colon, V.J., Luch, A., Seidel, A. and Baird, B.M., 1999, Cancer initiation by polycyclic aromatic hydrocarbons results from formation of stable DNA adducts rather than apurinic sites, Carcinogenesis, 20(10), 1885-1891.

Mukanganyama, S, Bezabih, M., Robert, M., Ngadjui, B.T., Kapche, G.F.W., Ngandeu, F. and Abegaz, B., 2011, The evaluation of novel natural products as inhibitor of human glutathione transferase P1-1, J. Enzyme Inhib. Med. Chem., 26(4), 460-467.

Murray, R.K., Granner, D.K., Mayes, P.A. and Rodwel, V.W., 1995, Biokimia Harper, translated by Andry Hartono, 9-11, Buku Kedokteran EGC, Jakarta.

Oakley, A., 2011, Glutathione transferases: a structural perspective, Drug. Metab. Rev., 43, 138151.

Prior, R.L., Wu, X. and Schaich, K., 2005, Standardized methods for the determination of antioxidant capacity and phenolics in foods and dietary supplements, J. Agric. Food Chem., 55, 2698A-J.

Ren, W., Qiao, Z., Wang, H., Zhu, L. and Zhang, L., 2003, Flavonoids: promising anticancer agents, Med. Res. Rev., 23(4), 519-534.
Robinson, T., 1995, Kandungan Organik Tumbuhan Tinggi, translated by Kosasih Padmawinata, 208-209, ITB, Bandung.

Rosaningtyas, L., 2006, Pengaruh ekstrak etanolik buah mengkudu (Morinda citrifolia L.) secara in vivo terhadap aktivitas glutation S-transferase ginjal tikus galur wistar, Thesis, Universitas Gadjah Mada, Yogyakarta.

Sheehan, D., Meade, G., Foley, V.M. and Dowd, C.A., 2001, Structure, function and evolution of glutathione transferases: implications for classification of non-mammalian members of an ancient enzyme superfamily, Biochem. J., 360, 1-16.

Sudibyo, M., 1997, Studi Inhibisi Kurkumin terhadap Aktivitas Enzim Glutation S-Transferase Liver Tikus yang Diinduksi Fenobarbital, Research Report of DPP-SPP, Faculty of Pharmacy UGM.

Sudibyo, M., 2000, Inhibition of glutathione S-transferase by curcumin and its derivatives : A molecular mechanism and qualitatives structure-activity relationships, Dissertation, Universitas Gadjah Mada, Yogyakarta.

Sudibyo, M. and Supardjan, 2002, Pengaruh obat-obat antiinflamasi pada aktivitas glutation S-transferase kelas mu dan pi, Research Report of Project Grant-QUE Project, Batch-1, Faculty Pharmacy UGM.

Van-Haaften, R.I.M., Haenen, G.R.M.M., van Bladeren, P.J., Bogaards, J.J.P., Evelo, C.T.A. and Aalt, B., 2003, Inhibition of various glutathione S-transferase isoenzymes by RRR-a-tocopherol, Toxicol. in Vitro, 17, 245-251.

Wang, M.Y., West, B.J., Jensen, C.J., Nowicki, D., Chen, S., Palu, A.K. and Anderson, G., 2002, Morinda citrifolia (noni): A literature review and recent advances in noni research, Acta Pharmacol. Sin., 23(13), 1127-1141.

West, B.J., Deng, S., Isami, F., Uwaya, A. and Jensen, C.J., 2018, The potential health benefits of noni juice: a review of human intervention studies, Foods, 7(58), 1-22. 